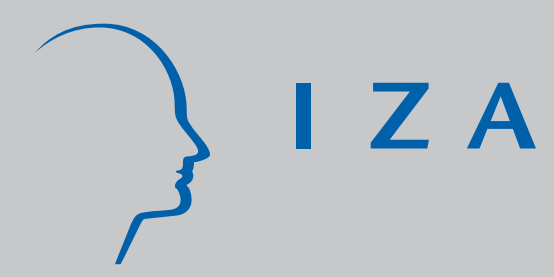

IZA DP No. 455

Unions and Establishment Performance: Evidence from the British Workplace Industrial/Employee Relations Surveys

J ohn T. Addison

Clive R. Belfield

March 2002 


\title{
Unions and Establishment Performance: Evidence from the British Workplace Industrial/Employee Relations Surveys
}

\author{
John T. Addison \\ Department of Economics, Moore School of Business \\ University of South Carolina, and IZA, Bonn \\ Clive R. Belfield \\ Teachers College, Columbia University
}

Discussion Paper No. 455

March 2002

\author{
IZA \\ P.O. Box 7240 \\ D-53072 Bonn \\ Germany \\ Tel.: +49-228-3894-0 \\ Fax: +49-228-3894-210 \\ Email: iza@iza.org
}

This Discussion Paper is issued within the framework of IZA's research area Welfare State and Labor Markets. Any opinions expressed here are those of the author(s) and not those of the institute. Research disseminated by IZA may include views on policy, but the institute itself takes no institutional policy positions.

The Institute for the Study of Labor (IZA) in Bonn is a local and virtual international research center and a place of communication between science, politics and business. IZA is an independent, nonprofit limited liability company (Gesellschaft mit beschränkter Haftung) supported by the Deutsche Post AG. The center is associated with the University of Bonn and offers a stimulating research environment through its research networks, research support, and visitors and doctoral programs. IZA engages in (i) original and internationally competitive research in all fields of labor economics, (ii) development of policy concepts, and (iii) dissemination of research results and concepts to the interested public. The current research program deals with (1) mobility and flexibility of labor, (2) internationalization of labor markets, (3) the welfare state and labor markets, (4) labor markets in transition countries, (5) the future of labor, (6) evaluation of labor market policies and projects and (7) general labor economics.

IZA Discussion Papers often represent preliminary work and are circulated to encourage discussion. Citation of such a paper should account for its provisional character. A revised version may be available on the IZA website (www.iza.org) or directly from the author. 


\section{ABSTRACT \\ Unions and Establishment Performance: Evidence from the British Workplace Industrial/Employee Relations Surveys}

An interesting aspect of British research on unions based on the Workplace Industrial/ Employment Relations Surveys has been the apparent shift in union impact on establishment performance in the decade of the 1990s compared with the 1980s - and the recent scramble to explain the phenomenon. In this contribution, we chart these changes along the dimensions of financial performance, labor productivity, employment, quits, absenteeism, industrial relations climate, and plant closings. Using the most recent workplace survey, we also investigate the controversial notion that union influence is positive where unions are strong and is negative where unions are weak. This notion, encountered in recent research in Britain (and Germany), emphasizes the benefits of the collective voice of unions, arguing that this voice is only 'heard' when the union is strong or a credible agent. We examine this contention for a fuller array of definitions of union influence and workplace performance measures. Overall, our discussion reveals some evidence that is consistent with reduced bargaining power in the wake of anti-union reform measures and heightened product market competition. On the other hand, there is little support for the recherché notion that stronger unions have a beneficial impact, yet weaker ones do not.

JEL Classification: J24, J51, J53, J58, J63, J65

Keywords: Union strength, hierarchy of effects, financial performance, labor productivity, employment change, quits, absenteeism, plant closings, employee attitudes

John T. Addison

Department of Economics

Moore School of Business

University of South Carolina

Columbia, SC 29208

USA

Tel.: +1-803-777-4608

Fax: +1-803-777-6876

Email: ecceaddi@darla.badm.sc.edu 


\section{Introduction}

One surprise in the British industrial relations literature is the seeming failure of established relationships in the principal datasets available to researchers - the Workplace Industrial/Employee Relations Surveys - to hold up through time; specifically, when effecting a comparison between the decade of the 1980s and the 1990s. Although the major focus of interest has been the attenuation of union effects, for which there are a number of potential explanations, there are other empirical irregularities concerning such factors as information and consultation, participation, and financial involvement that are fundamentally more opaque and which therefore continue to cast a shadow on easy interpretations of the former.

In the present paper, we focus on the union argument. We first examine union effects on financial performance, labor productivity, aspects of employment, and the climate of industrial relations. Since the intention is to uncover changes in union impact through time, we have also to consider evidence on the union premium. We round off our survey of these (disparate) effects with a discussion of union impact on plant closings. This might seem appropriate for either of two reasons: first, because evidence of plant closings could explain why negative union effects, where observed, need not prove pathological; and, second, because it could substantiate interpretations of sources of observed changes in other union effects. As we shall see, the sparse plant closings literature does neither in any obvious manner. Rather it raises new sets of issues, and in particular whether weakened unionism is consistent with improved performance. A new strand of the unions-and-economic-performance literature, exploiting collective voice and the agency role of unionism, has argued that strong unions imply better performance. Interestingly, this is echoed in the German literature, where it is argued that collective agreements reached at industry or regional level hold in check distributional bargaining at the workplace, allowing workplace representation to focus on issues having more to do with the size of the cake rather than matters of its distribution (see, for example, Hübler and Jirjahn, 2001). In the second part of this paper, therefore, we investigate whether more powerful unions are more responsible unions. Here, we reconsider the same performance outcomes reviewed earlier, but also link the new union construct to data on worker perceptions. 
A final section offers an interpretation of our findings. On balance, we conclude that many though not all of the associations considered here are after all consistent with a weakening in union influence - and hence with a reduction in the disadvantages of unionism - brought about by man-made and economic forces. But the separate contributions of legislation and heightened product market competition are not quantifiable. Further, it would be idle to pretend that we understand the sources of changes in the impact of other variables also evident in the WIRS/WERS. Finally, it is important to note that we are not discussing the macroeconomic role of unions. And this is the one area above all in which beneficial effects on employment and unemployment have been attributed to unionism or, more accurately, to coordinated wage bargaining. On the other hand, the standard industrial democracy case for unionism does not receive ringing endorsement when we attempt to go behind the collective voice argument.

\section{Union Effects on Establishment Performance Across the WIRS/WERS}

There is no doubt that unions declined in Britain after 1979, following a period of substantial growth. At that time some 53 percent of workers were union members but by 1999 this had fallen to 28 percent. Correspondingly, there has also occurred a sharp fall in the share of employees whose wages are set by collective bargaining: from 70 percent in 1980 to around 45 percent in the mid-1990s. Moreover, all indicators of union presence point in the same direction, and for all sectors other than the public sector (Machin, 2000).

Since 1980 there have also been some profound changes in observed union effects, some of which are more controversial than others. We preface our presentation of establishment performance outcomes with some brief remarks on the course of the unionnonunion differential, one of the more controversial areas. It has been conventional to report that the union premium remained more or less stable during the 1980s but declined fairly precipitously during the first half of the following decade for a variety of union measures (see respectively, Stewart, 1995; Hildreth, 1999). Today, it is often argued that the premium has evaporated (other than for specific groups such as women). The initial source of controversy was a dissonance between studies based on individual rather than workplace data, the latter showing a persistent premium of around 10 percent, cet. par. 
(e.g. Blanchflower, 1997). But more recent work using individual-level data seems to confirm the workplace findings (e.g. Machin, 2001). So, after all, the evidence does tend to favor a marked decline in the union differential. ${ }^{1}$

\section{(Table 1 near here)}

Turning to our first outcome indicator - profitability - almost all of the early British studies pointed to negative effects of various indicators of union presence on financial performance/profitability. Some of the more recent evidence is reported in Table 1. The starting point is the study by Machin and Stewart (1996) that identifies a sharp decline in the union effect on profitability over the first three WIRS. Note the finding that 1990 any negative effect was confined to closed shop or analogous situations in conjunction with some degree of market power. The second row contains the results of a replication of the previous study by Addison and Belfield (2001), using the most recent WERS. If anything, it points to a sharper retardation in the effect of union recognition.

The study in the third row of the table is of interest because it attempts to capture the effects of financial participation and employee involvement practices on financial performance. Identifying the union effect is secondary to this main concern. In particular, it is argued that employee involvement will be more capable of yielding a dividend where it is associated with financial participation - and, further, that different types of employee involvement and financial participation will vary in their impact on financial performance. Mixed effects are duly reported for union recognition: unions have positive impact where the organization practices downward communication and upward communication, but in the absence of such schemes the union effect is negative and statistically insignificant. However, Addison and Belfield's (2000) replication of this study (row 4) finds no statistically significant effect of union recognition for any concatenation of employee involvement and financial participation. Morever, these authors also report different effects for the key variables in the empirical model (as do Addison and Belfield, 2001, in replicating Machin and Stewart, 1996).

The study in row 5 of Table 1 allows for a wider variety of union measures. Booth and McCulloch (1999) find no evidence of a hierachy of (nonmanual) union effects on aggregate. However, disaggregation by union type - manual versus nonmanual - reveals such effects for nonmanual unions: the effect of 'recognition only' is negative 
and statistically significant and the presence of a closed shop increases the absolute value of the union effect. In contrast, manual unions have no discernible impact on financial performance. We note parenthetically that the main focus of this study is on bargaining over redundancy pay, which is not found to have any material effect on financial performance other than in nonmanual union regimes where the effect is strongly positive. Vulgo: firing constraints in the United Kingdom are relatively unimportant in impacting labor market flexibility.

The principal concern in the study by Conyon and Freeman (2001) (row 6) is the role of (four types of) financial participation in influencing financial performance, so that the union effects for the 1998 WERS cited in the table are secondary - and, interestingly, never commented on in the paper. As can be seen, the association between union recognition and financial performance is negative and statistically significant throughout (i.e. irrespective of the form of financial participation). Unlike the row 3 study, it is argued that employee involvement and financial participation are complementary.

The final study by Menezes-Filho (1999) (row 7) is notable for its use of objective financial data, and incorporation of bargaining structure (and theory). The main result is that although union firms have lower profitability overall, that effect narrowed between 1984 and 1990 and had all but disappeared by the end of the sample period. That being said, consistent with the author's theoretical priors, there is evidence that profit retardation remains strongest in areas where unions enjoy greater bargaining power. Union bargaining power is reported to be greatest - and profitability to be even lower - in firms with only one establishment (vis-à-vis multiestablishment undertakings) and where different unions bargain jointly with the firm at the industry level

For their part, improvements in profitability are allied to union derecognition, the decrease in the number of establishments recognizing unions and, consistent with the above evidence, to changes from joint to separate bargaining and to decentralization of bargaining. Nevertheless, each result is conditional on increasing profitability due to the decreasing union recognition effect over time; so that restructuring of the bargaining relation is secondary.

(Table 2 near here) 
The sparse early British evidence points to negative effects of unionism on firm and establishment productivity, despite contemporaneous estimates of the union wage premium of around 10 percent (e.g. Machin, 1991). As before, the more recent evidence is surveyed in Table 2. The dominant theme of the newer literature is that unionized firms/plants increased their productivity most at the end of the 1980s (and arguably in 1979-84, too) and/or that there is no longer evidence of a productivity shortfall in union firms/establishments. The evidence is not overwhelming, however, so that it would be premature to claim more than what has been observed is a reduction in the disadvantages of unionism. The relevant factors here include the possibility that least productive unionized undertakings may have been evolved out of the system (for this reason the empirical suggestion that the union effects were most positive in situations where competitive pressures were more acute is not altogether compelling), the fact that the strongest productivity gains are actually reported for union derecognitions, and to some degree the odd timing of the observed spurts of improvement.

As in the case of parallel developments in profitability, reviewed earlier, it is conventional to ascribe the observed changes to the impact of the Thatcher reforms in conjunction with heightened competitive pressures. Thus, Gregg, Machin, and Metcalf (1993, p. 895) write that "the gains are the cumulative result of a regained managerial right-to-manage (bolstered by union weakening and increased competion)." On this view, union derecognitions are a signal to the workforce of a greater assertiveness on the part of management. At issue of course is whether the observed changes will persist (see section IV). Also worrying is the apparent shift in the effects of other covariates - not just the union argument - on the productivity outcome indicators in the WIRS/WERS. In this case, however, there is supportive evidence for at least the union effect from the nonWIRS/WERS studies summarized in Table 2.

(Table 3 near here)

We turn next to the evidence of union effects on employment, broadly interpreted. There is reasonable agreement in the WIRS/WIRS on the apparent role of unions in retarding employment growth or exaggerating employment reduction. As can be seen from the first panel of Table 3, there is the suggestion that unionized establishments in the 1980 s tended to grow by 3 percent less per year than their nonunionized counterparts. 
(Remarkably, a tendency of similar magnitude is observed in U.S. and Australian data see, respectively, Leonard, 1982; Wooden and Hawke, 2000.). There is some disputation as to these results reported by Blanchflower, Millward, and Oswald (1991) for 1980-84 because of the concern that unionized firms at this time were more likely to see an erosion of restrictive practices (partly allied to overmanning arrangements and demarcation), and hence more likely to be shedding labor. But this criticism does not seem to be unduly damaging. First, the organizational change measure in the WIRS used to proxy such reform of working conditions does not overturn the negative impact of the union density measure on employment for the specific time period under consideration. Second, Booth and McCulloch (1999) (row 2) report for later intervals that the union effect on employment is robust to the inclusion of organizational change measures. Subject to obvious limitations - the data-driven failure to model the dynamics of the employment adjustment process - there is a large measure of accord in repeated cross sections of the workplace surveys that union slow job growth.

That said, there is some lingering ambiguity as to some other relationships in the employment change equations. Thus, for example, Addison and Belfield (2001) (row 4) report very different findings for financial participation arguments than do Fernie and Metcalf (1995) (row 3). On the other hand, neither finds evidence of a hierarchy of union effects (i.e. greater retardation of employment growth/heavier employment decline in circumstances where unions are more powerful. In this connection, Bryson (2002b) has recently argued that stronger unions are more likely to bargain over employment so that one should not expect to see declines in employment for this subset of unions.

Finally, Table 3 contains information on union impact on quits and absenteeism rates (rows 5-8). Here there is no disagreement as between studies based on successive workplace studies as to the role of unions in reducing quits (rows 5-6), even if the WIRS/WERS data are less than ideal. Rather, disagreement instead centers on absenteeism rates: Addison and Belfield (2001) report sharply higher absenteeism rates in union regimes for WERS 98 whereas Fernie and Metcalf report no such association for WIRS 90 (rows 7-8). There has been no investigation in Britain of the effect of quits in improving productivity and of absenteeism in reducing it.

(Table 4 near here) 
Another outcome indicator that has attracted some scrutiny is the climate of industrial relations. Table 4 provides results from just three studies, each using management responses (those of employees are examined in the next section). As can be seen, the negative effects of union presence in its various guises detected in the WIRS 90 are not reflected in the successor WERS 98. It is not altogether clear whether we should regard the 'climate' of industrial relations as a determinant of economic outcomes or as a separate indicator. The standard approach has followed the latter route, sometimes treating it explicitly as an intervening variable to differentiate between types of management processes (see, for example, Ramsay, Scholarios, and Harley, 2000).

The study by Wood and de Menezes (1988) in row 1 of the table is of especial interest because of its attempt integrate the plethora of employee involvement and participative mechanisms used in many of the studies contained in Tables 1 through 4. Specifically, the authors test whether the schemes form a unity and can be used as indicators of a high commitment orientation on the part of management. Wood and de Menezes use latent variable analysis to search for identifiable patterns in the use of 23 such practices. Although they cannot identify high commitment management as a welldefined continuous variable, they are able to fit a latent class model to the data; that is, identify a progression of four types of high commitment management. The progression is high HCM, medium-low HCM, low-medium HCM, and low HCM.

As far as unionism is concerned, the authors first examine the association between union recognition and high commitment management. The relation between the two is weak. Neither high HCM nor low HCM workplaces are distinctive with respect to unionism. This suggests among other things that the tendency of the industrial relations literature to treat nonunion workplaces as a 'bleak,' authoritarian houses is erroneous. Second, having confirmed that high-commitment management is not replacing unionism, as it were, the establishment's HCM class is entered as an argument in conventional performance equations alongside unionism and controls for workplace characteristics and industry affiliation (there are three dummies, the default being high HCM plants). Row 1 in Table 4 simply reports results for the union covariate. As for the pro-productive role of high commitment management, the findings are disappointing not only with respect to the climate of industrial relations but also for the other outcome indicators 
(levels of and changes in labor productivity, financial performance, employment growth, quits, and absenteeism). In no case do high HCM plants perform better than all the others on any performance criteria. Thus, for example, although plants characterized by high HCM do have greater employment growth and better financial performance than the two medium HCM categories, this does not hold vis-à-vis low HCM establishments. The implicit suggestion that different types of firm can perform differently according to the outcome measure is also encountered in other of the studies reviewed here (see, in particular, Fernie and Metcalf, 1995.) We return to this issue in section IV.

(Table 5 near here)

The final outcome indicator we examine is plant closings. On this occasion, all the extant studies are summarized in Table 5. The evidence is again mixed. Studies based on WIRS 84 reveal scant evidence of any association between unionism and plant closings, irrespective of the union measure (see rows 1 and 2 of the table). Note also the absence of a hierarchy of union effect: more powerful unions, as proxied by the magnitude of the wage premium or presence of the closed shop, have no discernible incremental effect on closings.

The plot thickens when we come to consider the more recent evidence. Broadly speaking, the sign of the coefficient estimate for the union variable is positive and statistically significant in the two studies using WERS 98 (rows 3-4). But this broad result hides as much as it reveals. Although reporting a material and robust positive association between either of two measures of unionism - recognition for collective bargaining purposes and union coverage - Addison, Heywood, and Wei (2001) find that this holds only for establishments that are part of larger (i.e. multiestablishment) undertakings. For single-plant entities (here firms), the direction of the association is reversed. (All studies support the more general result that single independent plants are less likely to close than their counterparts that are part of multi-establishment undertakings). The authors interpret the former result as consistent with a decline in union bargaining power in the wake of a decade of anti-union legislation, either by emboldening employers in multi-plant enterprises to close unionized establishments, or by weakening union influence over employment in such settings (see Machin, 1993). The 
single plant result, on the other hand, is rationalized in terms of (differential) union concessions in conjunction with rents.

While not contesting these findings, the recent study by Bryson (2001) (row 4) offers a very different interpretation of the positive association between plant closings and unionism. Rather, it is now union weakness - accentuated by the legislation - that is said to explain the sea change in union effect detected in the more recent workplace survey. Bryson reports that where unions are strong the coefficient estimate for unionism is no longer statistically significant. Stronger unions are identified by the closed shop and a combination of high density, bargaining coverage and on-site representatives, inter al. The 'weak union' result is taken to be consistent with such unions being an ineffective voice for workers - and an inefficient agent for management as well - and conversely for strong unions. However, while downplaying rent seeking and emphasizing the ineffective voice/weakened agency function of weak unions, Bryson reports that where unions bargain over physical working conditions, the likelihood of closure is increased.

This review of the literature on union effects has uncovered evidence of seemingly important shifts in union impact over time. The evidence is largely consistent with reduced union bargaining power stemming from a decade of anti-union legislation in the 1980s and heightened product market competition. (However, we have cautioned that other associations evident in earlier WIRS data have also proved unstable, and we have altogether less compelling priors for these changes). As cases in point, we can cite the decline in the union wage premium and the improved financial performance and productivity of unionized plants vis-à-vis their nonunion counterparts. It would be stretching things too far to claim the same for the seeming disappearance of a negative union effect in the climate-of-industrial-relations equations, given the lack of variability in the outcome measure. Equally, the presence of some constants in the empirical literature - such as the role of unions in blunting employment growth and, more controversially, in elevating absenteeism - would underscore the claim that one is speaking of an ongoing reduction in the disadvantages of unionism rather a complete transformation of the entity.

Nevertheless, the recent plant closings literature has raised new questions, occasionally hinted at in parts of the performance literature, by virtue of the positive 
association between union presence and establishment dissolutions in the WERS 98. Although this positive association is by no means inconsistent with the improvement in performance story, the notion that union weakness is a culprit is seductive and needs to be addressed. In the next section, we subject this claim to very much closer scrutiny for other performance measures.

\section{Effects of Union Strength on Establishment Performance}

We now address directly the argument that the effects of unions vary according to union strength, using data on private sector workplaces from the WERS 98. Formally, the hypothesis is that stronger unions enhance establishment performance through effective 'voice' (and agency) but weaker unions impair performance (Bryson, 2002a, 2002b). We test this hypothesis using various definitions of union strength.

(Table 6 near here)

Table 6 reports on various definitions of union 'strength' across the 1,404 workplaces in the sample. Of the workplaces, 636 (45 percent) have at least one union that is recognized for pay bargaining purposes; the convention in the literature detailed above is to classify these as union workplaces (UNION). Within this sample of union workplaces, however, we can also identify unions that have relatively strong representation. Thus, for example, 521 union workplaces have an on-site union representative (REP), 270 workplaces have at least 75 percent workforce representation (union density, DENSE), while just 10 workplaces report a closed shop agreement (CSHOP).

Union strength may also be proxied by union involvement in workplace decisions and practices. In this connection, 188 unions are reported to negotiate across a range of issues rather than simply over pay (RANGE). In 98 workplaces, managers explicitly attributed a recent workplace change to a union decision or to union negotiation (CHANGE). And in 43 workplaces it is reported (again by the manager respondent) that unions had resisted workplace change (RESIST). In addition, we can identify workplaces where unions are welcomed by management and so have 'influence': 309 union workplaces have managers who declare that they 'favor unions' (FAVES), while 
management in a further 42 workplaces recommend union mwmbership to their workers (REC).

Finally, we can identify the number of unions at the workplace: 343 units have more than one union (MULTI1), of which 127 practice separate bargaining (MULTI2). Apart from their effects on workplace performance through work rules, multiple unions may exert greater influence than single unions by offering more power and voice for different workers. More narrowly, where workers are complements, separate bargaining in multiunion settings implies stronger unions. Even if the opposite holds true where workers are substitutes, the fact that employers have increasingly favored joint bargaining might imply that the MULTI2 category are still stronger unions. Accordingly, the hypothesis is that both MULTI1 and MULTI2 are indicative of greater union power.

In short, we can test the effects of union strength (as proxied by union types) on the range of outcome measures. Most of the workplace outcome measures can be examined: profitability; productivity and changes in productivity; employment, quits and absenteeism; and the climate of industrial relations (closings information is not available for use with the 1998 data).

In addition, we test for effects at the worker level. The WERS 98 included a survey of up to 25 employees per workplace. These employees were randomly selected, and they provided information on their personal characteristics and on conditions at the workplace (see Cully et al., 1999). Across the 1,404 workplaces, information is available on approximately 18,000 individuals. For these employees, the outcome measures selected are their reported sense of achievement from work, loyalty toward the organization (plus shared values and pride in the organization), and the log hourly wage. The first four of these measures capture worker attitudes and so approach more closely the notion of voice that is emphasized in the literature. Although workers may be more dissatisfied, they need not of course be less productive and so the workplace and workerlevel estimations should be considered together. The full range of outcome measures are described in Table 7.

\section{(Table 7 near here)}

We estimate ten separate equations per outcome indicator to identify the effects of unions (models 1-10). ${ }^{2}$ For each outcome, the more general specification is: 


$$
Y=\mathrm{a}_{0}+\mathrm{a}_{1} \mathrm{U}+\mathrm{a}_{2} \mathbf{Z}
$$

In equation (1), the outcome $Y$ is related to $\mathrm{U}$, the dummy variable capturing union recognition (recall that unions are recognized in 636 of the 1,404 workplaces), and to a vector $\mathbf{Z}$ of workplace characteristics (detailed at the foot of each appendix table). The sign, size, and significance of coefficient $a_{1}$ has been the primary focus of the literature. Estimation of this coefficient forms the basis of our model 1, and indicates the impact of unions on U.K. workplace performance in 1998.

To estimate the effects of different union types, the specification in equation (1) is modified as follows:

$$
Y=\mathrm{a}_{0}+\mathrm{a}_{1 \mathrm{~S}} \mathrm{U}_{\mathrm{S}}+\mathrm{a}_{1 \mathrm{~W}} \mathrm{U}_{\mathrm{W}}+\mathrm{a}_{2} \mathbf{Z}
$$

Here, the effect of union status is dichotomized into $U_{S}$ and $U_{W}$, to represent the nine types of unions in their strong and weak versions. These are models numbered 2-10. In the case of model 2, for example, $\mathrm{U}_{\mathrm{S}}$ takes the value of 1 if the workplace has a union with a union representative (as is the case in 521 workplaces) and $\mathrm{U}_{\mathrm{W}}$ takes the value of 1 for the balance of the union workplaces. To repeat, we simplify the exposition by referring to union types as 'strong' if they possess the characteristics listed in Table 6. Therefore, a strong union is one where there is a local representative, where union density exceeds 75 percent, and so on. Note that because of small number of closed shops in the WERS 98, we combine this argument with the management recommends unionism variable (to form REC/CSHOP); also, we should be cautious in our intepretation of the quit rate, although here we invoke the standard argument that lower quits are beneficial. The specification in equation (2) serves two functions. First, it indicates whether unions - strong or weak - affect workplace outcomes and worker attitudes and wages $\left(\mathrm{a}_{1 \mathrm{~S}}>0\right.$, $\mathrm{a}_{1 \mathrm{w}}>0$ ). Second, it allows us to see whether a strong union has different effects from a weak union $\left(a_{1 S} \neq a_{1 w}\right)$.

The coefficients $a_{1}, a_{1 S}$ and $a_{1 w}$ for each model are reported in the appendix tables. They capture the effect of each union type in its strong and weak versions, relative to a workplace with no union. The hypothesis - stronger unions are relatively beneficial - can be examined by looking at the differences between coefficients $a_{1 S}$ and $a_{1 w}$. However, a strict test is where the coefficient on a strong union is statistically significant and different from the coefficient on weak union. We perform this strict test by 
estimating the equations $2-10$, but using weak union status as the default category instead of nonunion status. With this specification, the coefficient on strong union status indicates a statistically significant effect relative to a weak union. In addition, we perform two weaker (less informative) tests. The first simply compares the absolute value of the point estimates to see which of $\mathrm{a}_{1 \mathrm{~S}}$ or $\mathrm{a}_{1 \mathrm{w}}$ is the greater (ignoring significance levels). The second test is based on estimation of models 2 through 10, but now for the 636 union workplaces alone. A dummy variable is used to identify the stronger type of union, so that the sign and significance of its coefficient estimate indicates the relative effect of stronger unions in the union firmament.

Equations (1) and (2) are fitted for each of the workplace and worker outcomes. Robust regression, probit, and ordered probit estimation techniques are used, as appropriate for each outcome variable. For the worker-level estimations, the union coefficients identify the impact of being in a firm where the union is recognized (irrespective of the individual's own union status). Detailed controls for individual worker characteristics are included. But note in particular that the wage equation is simplified, and does not adjust for differential selection of workers into unionized workplaces.

(Table 8 near here)

Summary findings for the key union measures across the ten models are given in Tables 8 and 9. (The coefficient estimates that indicate union effects are reported in Appendix Tables A.1 through A.4.) Table 8 deals with the (seven) workplace outcomes. For each outcome, row 1 shows the direction and significance of the union recognition effect (coefficient $\mathrm{a}_{1}$ ). Rows 2 and 3 report the results of the strict test. Row 2 reports union types where the coefficient on the stronger version is 'beneficial' relative to the weaker version $(p<0.05)$. If the revisionist notion holds, we would expect stronger unions to be identifiable in this row. Row 3 reports those union types where a strong union has an 'adverse' effect, relative to a weak union $(\mathrm{p}<0.05)$. This row should indicate where unions have a monotonic effect: stronger unions having 'worse' effects than weaker unions. Overall, although the results are not fully consistent, the evidence tends toward rejection of the revisionist notion that strong unions are better for performance than toward acceptance of it. 
For profitability, the general union effect is negative but not statistically significant (row 1). Nevertheless, the type of union that resists change does have a statistically significant adverse effect on profitability: the stronger union type has a more adverse effect, and so the recherché notion is rejected (row 2).

For labor productivity, there is again no clear general effect of unionism (the coefficient estimate in row 1 is only significant at the .10 level). Yet, there are four union types where a stronger union has a clearly adverse effect (and a weaker union does not). These are circumstances where the union resists change, where union density is above 75 percent, where the union bargains over a range of issues, and where multiple unions bargain separately. This evidence cautions against the idea that stronger unions are more effective. And there is no support for the revisionist notion in terms of labor productivity change. Instead, we do observe that the higher is union density, the slower is productivity growth.

For employment growth, union presence in general has deleterious effects that are statistically significant: coefficient $a_{1}$ is negative and well determined. Interestingly, where the union is 'weakened' by the absence of a workplace representative, this adverse effect on employment growth is not observed. On the other hand, in workplaces where the union resists change there is apparently no adverse effect either.

For quits and absenteeism, the results in general show quits to be lower and absenteeism to be higher in all union workplaces. As noted earlier, lower quits are conventionally viewed as a positive outcome and although we remain agnostic on the issue - since quits could be too low in union regimes - we follow the convention and treat reduced quits as beneficial. It can be seen that quits are further reduced in union plants with local representatives, in multiple union settings, and in circumstances where union density is high. For its part, however, absenteeism is further elevated where management favors unions, or where union density is higher. Finally, with respect to the climate of industrial relations, there are essentially no differences as between workplaces without unions, with strong unions, or with weak unions. Only in one case - where the union is strong enough to resist change - is the workplace climate impaired to a significant extent.

(Table 9 near here) 
Table 9 provides a corresponding summary of the employee results, although it will be recalled that the union variable is again measured at workplace level. Row 1 shows an interesting and persuasive result: all the worker satisfaction measures are lower in union workplaces, but the wage is higher. From the perspective management, we can denote them as 'worse.' When we look at differences according to the strength of the union, there are some distinctions. Seemingly, the negative impact of unions on loyalty and pride can be obviated if the workplace has a closed shop or management recommends union membership. That said, there is a strong link between adverse outcomes and the strength of the union for each of the worker measures (row 3). The negative union impact on worker attitudes is exacerbated by having a stronger union, particularly one that has a higher density, a local union representative, or multiple unions. Similarly, union wages are higher, the stronger the union.

Overall, the strict test shows only the most limited support for the recherché notion that strong unions are beneficial and weak ones are not. This conclusion is supported by the two other weaker tests that we performed, where both tests do not include the quit rate outcome because of its ambiguity. The first weak test indicates the impact of union strength through a comparison of the coefficients for strong and weak unions across each of the 12 outcomes for each of 9 union types based on specification (2) above (see the appendix tables). In 89 of these 108 comparisons, the coefficient on the stronger version of the union is 'worse' than the coefficient on the weaker version of the union. The second weak test involved comparison of the coefficient on 'strong union status' in estimations applied only to union firms. In 36 of the 108 comparisons, the coefficient for the strong union is statistically significant with an adverse effect $(p<0.05)$, whereas in only 3 cases was the coefficient statistically significant with a beneficial effect. Taken together, our results support what is to us the more plausible conclusion that the adverse effects of unions increase with the strength of the union.

\section{Interpretation}

In the present paper, we have discussed changes in the impact of unionism on establishment performance, inter al., as revealed through analysis of successive WIRS/WERS, and examined the modern notion that the decline in union influence has 
downside efficiency consequences. Our findings may be summarized as follows. First, there is evidence of a diminution of union effects on wages, financial performance and productivity through time. As the measures are not commensurate, we cannot quantify the degree of efficiency improvement stemming from these changes in unionized regimes. Arguably, the economic impact could have been small, but we incline to the view that more than redistribution (from workers) has been involved. But by the same token, certain unfavorable effects of unionism persist (e.g. slower employment growth and higher absenteeism) and so it is also appropriate to conclude that there has been a reduction in the disadvantages of unionism, not a reversal. Larger efficiency gains are likely to have accrued from the decline in union density and the ability of newly formed enterprises to avoid union organization.

Second, we have found little direct support for the revisionist notion that the reduction in union power is responsible for worse outcomes. The argument that unions have to be strong to be an effective vehicle of pro-productive voice and to act as an authoritative agent of the employer principal is, we submit, pushing things too far. We have provided evidence against this notion for all of the outcome indicators earlier considered in our survey of the literature and, for completeness, for a variety of employee attitudes as well. The specific case of plant closings requires more attention. Given that there is no evidence of a union effect on plant closings in the WIRS 84 , why should the reduction in union power have yielded a significantly positive association between union recognition/density and plant closings in the WERS 90? The Bryson (2001) argument would be that the legislation led to weaker unions that could neither deliver proproductive voice nor act as a responsible agent of the employer. We favor the alternative efficiency argument that there were too few closings in earlier years. In other words, we would argue from the finding for mutiestablishments in the literature (see Table 5, row 3 ) that management in such undertakings have taken the opportunity to rid themselves of inefficient plants. This contention gels with the reasoning of Manning (1993), who argues that the requirement for pre-strike ballots (under the Conservative administration's Trade Union Act of 1984) may have led to a loss of union influence over employment. Unions, so the argument goes, had hitherto kept open unprofitable plants by threatening to strike 
profitable ones. The new need to ballot members destroyed the credibility of this mechanism because workers whose jobs were not in jeopardy would not vote for a strike.

Caveats attach to the interpretation that the workplace surveys unambiguously reveal evidence of a decline in union influence. In the first place, although we have not dwelt on variables other than unionism, major changes in the effects of such factors as employee involvement and financial participation are also evident in the data. These are a cause for some concern because we have few priors for the observed shifts. It is true that there were some differences in question design as between WIRS 90 and WERS 98 (e.g. more detailed questions on employee involvement) but it seems unlikely that here were major differences in the composition of the workplaces. It is of course possible that in the case of employee involvement and participation that WIRS 90, for example, disproportionately sampled the innovators and WERS 98 the second movers. Morever, the focus on individual employee involvement schemes rather than the bundles suggested by more recent research may mean that like has not been compared with like. Again, by analogy with conventional payment-by-results schemes, individual employee involvement mechanisms may be subject to a cycle of emaciation and decay. That being said, there is also the issue of a changed impact of certain economic opposed to industrial relations measures on the outcome indicators (e.g. in the effect of market power on financial performance).

And there remain specific concerns with the union results themselves. For example, in an analysis of the WERS 98 Panel, not reported here, we found some contradictory evidence (Addison and Belfield, 2002). First of all, a standard fixed effects approach using first-differences did confirm that changes in union recognition had no discernible impact on two main outcome indicators of (changes in) financial performance and labor productivity. Second of all, however, when we relaxed this overly restrictive form by allowing for changes in union recognition in both directions and unchanged union status (the default being no recognition at any time), the coefficient estimate for the latter variable was both negative and statistically significant. For their part, the introduction and abandonment of unionism led to neither deterioration nor improvement in the outcome indicators. Of course, there are unsettled issues such as the effects of sample attrition in the panel of establishments over time and the difficulty of measuring 
changes in performance on the basis of categorical measures. Nevertheless, these findings provide some further grounds for caution.

A final and necessarily unresolved issue is the future course of union impact. New legislation in the form of the 1999 Employment Relations Act favors unionism in a number of ways, most obviously perhaps by establishing a statutory recognition procedure for all firms employing more than 20 workers (see, for example, Wood and Godard, 1999). Firms are required to recognize a trade union if a majority in the relevant bargaining unit vote in favor and at least 40 percent of the unit support the union. There is also a procedure for automatic recognition where 50 percent of the unit workforce are already union members. The legislation also gives the right for all workers to be accompanied by a trade union representative in grievance and disciplinary proceedings, relaxes the laws on strike balloting, and extends special protection against dismissal to strikers. It is widely accepted that these measures will facilitate unionism and increase union bargaining power. If, however, the new economy is viewed as a powerful constraint on unionism, then pan-European legislation may offer a much more important crutch to the British union movement. We refer in particular to new EU mandates that favor general systems of worker representation, such as the recently passed directive on national systems for informing and consulting workers. For a number of reasons, then, we have grounds for anticipating future iterations of the workplace survey with more than the usual interest. 


\section{Acknowledgments}

The authors acknowledge the Department of Trade and Industry, the Advisory, Conciliation and Arbitration Service (ACAS), the Economic and Social Science Research Council, and the Policy Studies Institute (PSI) as originators of the 1998 Workplace Employee Relations Survey (WERS 98), and the Data Archive at the University of Essex as the distributor of the data. None of these organizations bears any responsibility for the authors' analysis and interpretation of the data. This paper has been prepared for the $23^{\text {rd }}$ Annual Middlebury Economics Conference, The Changing Role of Unions, organized by Professor Phanindra V. Wunnova and to be held at Middlebury College, Middlebury, Vermont, April 13-14, 2002.

\section{Endnotes}

1. A very recent study by Bryson (2002a) adopts a semi-parametric worker-matching approach to measure the union premium. It is reported that only in already covered workplaces are union members in receipt of a wage premium and then only if the workplace is more than 50 percent organized or the plant is aged 21 years or more. The postmatching differential for the entire private sector is a statistically insignificant 3.5 percent.

2. Throughout, we report unweighted results. The WERS 98 weights were derived so as to make the entire survey of public and private sector workplaces representative of the U.K. economy. The findings are largely unchanged when weights are applied - full details are available from authors on request. 


\section{References}

Addison, John T., and Clive R. Belfield. 2000. "The Impact of Financial Participation and Employee Involvement on Financial Performance: A Re-estimation Using the 1998 WERS." Scottish Journal of Political Economy 47 (November): 571-583.

Addison, John T., and Clive R. Belfield. 2001. "Updating the Determinants of Firm Performance: Estimation using the 1998 WERS." British Journal of Industrial Relations 39 (September): 341-366.

Addison, John T., and Clive R. Belfield. 2002. "The Impact of Unions and Employee Involvement on Workplace Performance: Panel Data Evidence from the United Kingdom." Unpublished Paper, Department of Economics, University of South Carolina.

Blanchflower, David G. 1997. "Changes over Time in Union Relative Wage Effects in Great Britain and the United States," Unpublished paper, Dartmouth College.

Blanchflower, David G., Neil Millward, and Andrew J. Oswald. 1991. "Unionism and Employment Behavior." Economic Journal 101 (July): 815-834.

Booth, Alison L., and Andrew McCulloch. 1999. "Redundancy Pay, Unions and Employment." Manchester School 67 (June): 346-366.

Bryson, Alex. 2001. "Unions and Workplace Closure in Britain, 1900-1998." Unpublished paper, Policy Studies Institute, October.

Bryson, Alex. 2002a."The Union Membership Premium: An Analysis Using Propensity Score Matching." Unpublished Paper, Policy Studies Institute, January.

Bryson, Alex. 2002b. "Unions and Workplace Performance: What is Going On?" Unpublished Paper, Policy Studies Institute.

Conyon, Martin J., and Richard B. Freeman. 2001."Shared Modes of Compensation and Firm Performance: U.K. Evidence." Working Paper 8448, National Bureau of Economic Research, August.

Cully, M., S. Woodland, A. O'Reilly, and G. Dix. 1999. Britain at Work: As Depicted by the 1998 Workplace Employee Relations Survey. London: Routledge.

Cully, M., S. Woodland, A. O'Reilly, and G. Dix. 1999. Britain at Work: As" 1999.

Fernie, Sue, and David Metcalf. 1995. "Participation, Contingent Pay, Representation and Workplace Performance: Evidence from Great Britain." British Journal of Industrial Relations 33 (September): 379-415.

Hildreth, Andrew. 1999. "What Has Happened to the Union Wage Differential in Britain in the 1990s?" Oxford Bulletin of Economics and Statistics 61 (May): 5-31. 
Hübler, Olaf and Uwe Jirjahn. 2001. "Works Councils and Collective Bargaining in Germany: The Impact on Productivity and Wages." Discussion Paper No. 322, Institute for the Study of Labor (IZA), July.

Leonard, Jonathan S. 1992. "Unions and Employment Growth." Industrial Relations 31 (Winter): 80-94.

Machin, Stephen. 1991. "The Productivity Effects of Unionism and Firm Size in British Engineering Firms." Economica 58 (November): 479-490.

Machin, Stephen. 2000. "Union Decline in Britain." British Journal of Industrial Relations 38 (December): 631-6445.

Machin, Stephen. 2001."Does It Still Pay to be in a Union or Join a Union?" Unpublished Paper, University College London.

Machin, Stephen, and Mark Stewart. 1996. "Trade Unions and Financial Performance." Oxford Economic Papers 48 (April): 213-241.

Manning, Alan. 1993. "Pre-Strike Ballots and Wage-Employment Bargaining." Oxford Economic Papers 45 (July): 422-429.

Menezes-Filho, Naercio. 1997. "Unions and Profitability over the 1980s: Some Evidence on Union-Firm Bargaining in the United Kingdom." Economic Journal 107 (May): 651670 .

McNabb, Robert, and Keith Whitfield. 1998. "The Impact of Financial Participation and Employee Involvement on Financial Performance." Scottish Journal of Political Economy 45 (May): 171-187.

Moreton, David. 1999. "A Model of Labor Productivity and Union Density in British Private Sector Unionized Establishments." Oxford Economic Papers 51 (April): 322-344.

Ramsay, Harvie, Dora Scholarios, and Bill Harley. 2000. "Employees and HighPerformance Work Systems: Testing inside the Black Box." British Journal of Industrial Relations 38 (December): 501-531.

Stewart, Mark. 1995. "Union Wage Differentials in an Era of Declining Unionization." Oxford Bulletin of Economics and Statistics 57 (May): 143-166.

Wooden, Mark, and Anne Hawke. 2000. "Unions and Employment Growth: Panel Data Evidence." Industrial Relations 39 (January): 88- 107. 
Wood, Stephen, and Lilian de Menezes. 1998. "High Commitment Management in the U.K.: Evidence from the Workplace Industrial Relations Survey, and Employers' Manpower and Skills Practices Survey." Human Relations 51 (4) 485-515.

Wood, Stephen, and John Godard. 1999. "The Statutory Recognition Procedure in the Employment Relations Bill: A Comparative Analysis." British Journal of Industrial Relations 37 (June): 203-244. 
Table 1: Union Effects on Profitability

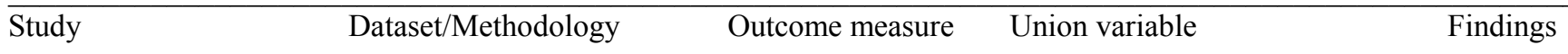

1. Machin and Stewart (1996).

WIRS 80, WIRS 86; WIRS

90. Ordered Probit.

\section{Addison and}

Belfield (2001).

3. McNabb and

Whitfield (1998).

WIRS 90. Probit.

WERS 98. Ordered probit.

Financial

performance

Financial

performance better

than average.

As above.

As above.

\section{Addison and}

Belfield (2000)

5. Booth and

McCulloch (1999).

WIRS 90. Ordered probit.

Financial

performance.

WERS 98. Ordered probit.

Financial

performance.

Freeman (2001).

7. Menezes-Filho (1997).

Sample of 494 firms, 198490. Pooled regressions, and sales. fixed effect specification. (manual).

As above.

Union
Union recognition (manual), closed shop/management recommends unionism

Union recognition.

(2)
employee involvement schemes, and is negative and statistically significant in their absence. participation mechanisms

Union recognition, closed shop; manual and nonmanual union recognition, manual closed shop, nonmanual closed shop.

Union recognition.

recognition/derecognition; bargaining structure. ificant in conjunction with financial participation. Union effect positive and statistically significant in the presence of

Coefficient estimate for union recognition statistically insignificant irrespective of employee involvement and financial

Negative effect of union recognition halved during the 1950s. By 1990 a significantly negative effect was confined to the closed shop. Moreover, that effect was conditional on presence of market power (as proxied by relative size of the establishment).

Coefficient estimates for union recognition and closed shop/management recommends unionism variables statistically insignificant throughout.

Union effect hinges on interaction with financial participation and employee involvement mechanisms. Union effect statistically

Positive and statistically significant effect of union recognition; negative and statistically significant effect of closed shop. But these overall effects hinge on union type. Coefficient estimates for recognition and closed shop are only statistically significant for nonmanual unions.

Coefficient estimates for union recognition negative and statistically significant throughout.

Coefficient estimates for union recognition negative and statistically significant but declining through time. Strongest negative effects observed in single establishment firms and where different unions bargain jointly with the firm at the industry level. Fixed effects specifications show that derecognized firms have faster increases in profitability. Also fragmentation of bargaining structure associated with higher profitability.

Note: Unless otherwise indicated, financial performance is based on a five-element categorical measure derived from the manager respondent's assessment of the financial performance of the establishment relative to others in the same industry. 
Table 2: Union Effects of Productivity and Changes in Productivity

\begin{tabular}{|c|c|c|c|c|}
\hline Study & Dataset/Methodology & Outcome measure & Union measure & Findings \\
\hline $\begin{array}{l}\text { 1. Gregg, } \\
\text { Machin, and } \\
\text { Metcalf. (1993) }\end{array}$ & $\begin{array}{l}328 \text { trading firms from } \\
\text { EXSTAT, 1984-89. } \\
\text { Production function } \\
\text { estimated using panel } \\
\text { regression methods. }\end{array}$ & $\begin{array}{l}\text { Growth in log real } \\
\text { sales. }\end{array}$ & $\begin{array}{l}\text { Union recognition, changes in } \\
\text { union status. }\end{array}$ & $\begin{array}{l}\text { For union recognition along, the union effect is negative and statistically } \\
\text { insignificant for 1984-97, but positive and statistically significant for } \\
1988-89(+3-4 \%) \text {. For changes in union status, repudiation of the closed } \\
\text { shop has no incremental impact over (favorable) effect of union presence } \\
(1988-89) \text { but derecognitions considerably elevate differential productivity } \\
\text { growth of union sector. }\end{array}$ \\
\hline
\end{tabular}
2. Conyon and
(i) 284 firms, 1995-98.
Log real sales. Union recognition.
Union effect negative but statistically insignificant throughout.

Freeman

Fixed effects production

(2001).

function estimates.

(ii) WERS 98. Ordered probit.

Relative labor productivity.

\section{Moreton \\ (1999). \\ WIRS 98. Ordered probit.}

\section{Relative labor productivity and union density.}

$\begin{array}{ll}\begin{array}{l}\text { 4. Fernie and } \\ \text { Metcalf (1995). }\end{array} & \text { WIRS 90. } \\ & \text { (i) Relative labor } \\ \text { productivity. }\end{array}$

$\begin{array}{lll}\text { 5. Addison and } & \text { WERS 98. } & \text { (i) As above. } \\ \text { Belfield (2001). } & \text { (ii) As above. } & \text { As above. }\end{array}$

(ii) Labor As above.

productivity improvement, 1987-90.
(ii) As above. As above.

\section{Union bargaining power, proxied by separate multi- unionism and firm

\begin{abstract}
Multiunionism associated with significantly lower productivity. Where management recommends unionism there is a positive effect on labor productivity. Also some suggestion that union effect might be positive where labor demand elasticity is higher.
\end{abstract} endorsement of union membership, inter al.

Union recognition alone. Preentry closed shop, post-entry closed shop, management recommends union membership, union recognition only.
For the one-dimension measure, the union effect is negative but only marginally significant. For the fuller representation, no hierarchy of effect beyond union recognition only, which is negatively signed and highly significant.

For the one-dimension dimension measure, the union effect is negative but only marginally significant. For the fuller representation, only the preentry closed shop is associated with significantly lower productivity growth.

Coefficient estimates for each union measure are negative but statistically insignificant throughout.

For union recognition alone, the union effect is positive and statistically significant. For the fuller representation, no hierarchy of effect beyond union recognition only, which is again positively signed and highly significant.

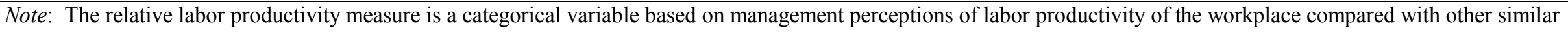

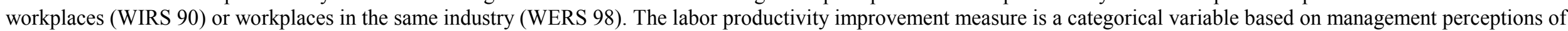
the level of labor productivity at the survey date relative to 3 years earlier (WIRS90) or 5 years earlier (WERS 98).
} 
Table 3: Union Effects on Employment, Quits, and Absenteeism

\begin{tabular}{lllll}
\hline Study & Dataset/Methodology & Outcome measure & Union measure & Findings
\end{tabular}

Employment

1.Blanchflower, WIRS 84. OLS

Millward, and

Oswald (1991)

\section{Booth and \\ McCulloch \\ (1999).}

\section{Fernie and}

Metcalf (1995)

WERS 90. OLS

WIRS 90. OLS. dependent variable

\section{Addison and Belfield (1991)}

WERS 98. OLS.

Quits

5. Fernie and

Metcalf (1995)

WIRS 80. OLS ending with survey
6. Addison and

Belfield (2001)
Change in log employment, 1989-90 and 1987-90. employment change equation as coefficient estimate on lagged approximates 1).

Change in employment 1984-90.

Change in employment, As above. 1993-98.

Resignations (plus retirements and deaths) as a proportion of total employment. Annual percent over year date.

Union recognition; union density; post-entry closed shop, pre-entry closed shop, membership.

Union recognition.

Union recognition only; pre-entry closed shop, post-entry closed shop, management recommends unionism, recognition alone.

As above.

As above.

As above.
Coefficient estimate for union recognition is negative and statistically significant. Effect of density is better determined. Together the recognition and density results imply that union establishments contract 3 percentage points more per year than their nonunion counterparts. Allowing for different union types, union membership and pre-entry closed shop are associated with lower employment growth (though the latter variable is poorly determined) while the effect of the post-entry closed shop is positive and statistically significant.

Coefficient estimate for union recognition is negative and statistically significant throughout. The union-induced reduction in employment growth is $2.6 \%(5.7 \%)$ for $1989-90(1987-90)$

For union recognition only, the association between employment change and union recognition is negative and statistically significant. For the fuller characterization of unionism, the coefficient estimates for all but the post-entry closed shop are negative and highly statistically significant. No hierarchy of effect.

For union recognition only, the association between employment change and union recognition is negative and highly statistically significant. For the fuller characterization of unionism, only the two weaker measures of union presence are associated with a material reduction in quits.

Union recognition only variable is associated with statistically significant reduction in quits measure. The same results holds for each of the four measures of union presence but again no hierarchy of union effect.

Union recognition only variable is associated with statistically significant reduction in quits measure. But for the (three) measures of union presence only the weakest is associated with a statistically significant reduction in quits. 
Absenteeism

7. Fernie and

Metcalf (1995).

8. Addison and

Belfield (2001)
WIRS 90. OLS.

Proportion of

employees sick or

absent, monthly rate.

WERS 98. OLS

As above, annual rate
No discernible impact of unionism on absenteeism irrespective of union measure.

Union recognition only variable is associated with statistically significant increase of absenteeism. Also true for union recognition alone for wider measures. 
Table 4: Union Effects on the Climate of Industrial Relations

\begin{tabular}{|c|c|c|c|c|}
\hline Study & Dataset/Methodology & Outcome measure & Union measure & Findings \\
\hline $\begin{array}{l}\text { 1. Wood and de } \\
\text { Menezes } \\
\text { (1998). }\end{array}$ & $\begin{array}{l}\text { WIRS 90; } \\
\text { Employers' } \\
\text { Manpower and Skills } \\
\text { Practices Survey. } \\
\text { Ordered probit. }\end{array}$ & $\begin{array}{l}\text { Quality of management/ } \\
\text { employee relations. }\end{array}$ & Union recognition. & $\begin{array}{l}\text { Coefficient estimate for union recognition is negative and statistically } \\
\text { significant. }\end{array}$ \\
\hline $\begin{array}{l}\text { 2. Fernie and } \\
\text { Metcalf (1995). }\end{array}$ & $\begin{array}{l}\text { WIRS 90. Ordered } \\
\text { probit. }\end{array}$ & $\begin{array}{l}\text { Quality of management/ } \\
\text { employee relations. }\end{array}$ & $\begin{array}{l}\text { Union recognition; pre- } \\
\text { entry closed shop, post- } \\
\text { entry closed shop, } \\
\text { management recommends } \\
\text { unionism, and union } \\
\text { recognition only. }\end{array}$ & $\begin{array}{l}\text { Coefficient estimate for union recognition alone is negative and marginally } \\
\text { statistically significant. Of the four more detailed measures of union presence } \\
\text { statistically significant negative coefficients are reported for the pre-entry } \\
\text { closed shop and union recognition only. }\end{array}$ \\
\hline $\begin{array}{l}\text { 3. Addison and } \\
\text { Belfield (2001). }\end{array}$ & $\begin{array}{l}\text { WERS 98. Ordered } \\
\text { probit. }\end{array}$ & $\begin{array}{l}\text { Quality of management/ } \\
\text { employee relations. }\end{array}$ & As above. & $\begin{array}{l}\text { In all cases, the coefficient estimate for the union variable is positively signed } \\
\text { but statistically insignificant. }\end{array}$ \\
\hline
\end{tabular}

Note: The quality of management/employee relations dependent variable is based on management responses on a seven-point scale ranging from "very good" to "very poor." In each of the above studies, the seven-point scale is collapsed to a five-point scale by combining the last three categories into one on frequency of response grounds. 
Table 5: Union Effects on Plant Closings

\begin{tabular}{|c|c|c|c|c|}
\hline Study & Dataset/Methodology & Union variable & Controls & Findings \\
\hline 1. Machin (1995). & $\begin{array}{l}1984 \text { WIRS, using data on } \\
\text { plants that subsequently } \\
\text { closed from the WIRS 1984- } \\
90 \text { Panel. Probit model. }\end{array}$ & Union recognition. & $\begin{array}{l}\text { Log number of employees, proportion nonmanual } \\
\text { workers, single plant, manufacturing dummies, } \\
\text { below average financial performance, operating well } \\
\text { below capacity. }\end{array}$ & $\begin{array}{l}\text { Union recognition effect } \\
\text { statistically insignificant both } \\
\text { overall and by type of union } \\
\text { (manual and nonmanual), and in the } \\
\text { presence or otherwise of the closed } \\
\text { shop. Result robust to inclusion of } \\
\text { one-digit industry dummies. }\end{array}$ \\
\hline 2. Stewart (1995). & As above. Probit model. & $\begin{array}{l}\text { Predicted mean union } \\
\text { wage differential. }\end{array}$ & $\begin{array}{l}\text { Log number of employees, proportion nonmanual } \\
\text { workers, operating well below capacity, } \\
\text { manufacturing dummy. }\end{array}$ & $\begin{array}{l}\text { Union wage differential statistically } \\
\text { insignificant throughout. }\end{array}$ \\
\hline $\begin{array}{l}\text { 3. Addison, Heywood, } \\
\text { and Wei (2001). }\end{array}$ & $\begin{array}{l}1990 \text { WIRS, using data on } \\
\text { plants that subsequently } \\
\text { closed from WERS 1990-98 } \\
\text { Panel. Probit model. }\end{array}$ & $\begin{array}{l}\text { Union recognition; union } \\
\text { coverage. }\end{array}$ & $\begin{array}{l}\text { Establishment size, establishment age, proportion } \\
\text { female, proportion manual, proportion } \\
\text { professional/technical, proportion short-term } \\
\text { contracts, wide range of employee-involvement and } \\
\text { participation mechanisms, industrial relations } \\
\text { climate, technology variables, flexibility at } \\
\text { workplace, change in ownership, market power, } \\
\text { layoff experience, export exposure, regional } \\
\text { unemployment rate, one-digit and more detailed } \\
\text { (three or four digit) industry controls. }\end{array}$ & $\begin{array}{l}\text { Robust positive and statistically } \\
\text { significant association between } \\
\text { union measures and probability of } \\
\text { plant closure. But the result is } \\
\text { driven by plants that are part of } \\
\text { multi-establishment undertakings. } \\
\text { For single-establishment firms, the } \\
\text { union effect(s) is negative and } \\
\text { generally statistically insignificant. }\end{array}$ \\
\hline 4. Bryson (2001). & As above. Probit model. & $\begin{array}{l}\text { Union recognition; union } \\
\text { strength ( } 3 \text { measures); } \\
\text { union type; number of } \\
\text { unions; bargaining } \\
\text { arrangements (e.g. single } \\
\text { vs. joint bargaining); and } \\
\text { bargaining scope. }\end{array}$ & $\begin{array}{l}\text { Industry-level union density, log number of } \\
\text { employees, proportion non- manual, single plant, } \\
\text { (10) regional dummies, (18) two-digit industry } \\
\text { controls, degree of competition, use of flexible } \\
\text { contracts, financial performance better than average, } \\
\text { operating considerably below capacity, increase in } \\
\text { employment. }\end{array}$ & $\begin{array}{l}\text { Union measure(s) positively } \\
\text { associated with plant closure. But } \\
\text { magnitude and significance of the } \\
\text { effect is sensitive to form of } \\
\text { measure. Statistically significant } \\
\text { effects where union is weak, for } \\
\text { manual worker unions, single } \\
\text { unions, and where union bargains } \\
\text { over physical working conditions. }\end{array}$ \\
\hline
\end{tabular}


On-site union representative (REP)

Multiple unions (MULTI1)

Management 'favors unions' (FAVES)

$75 \%+$ union density at workplace (DENSE)

Union negotiates across range of issues (RANGE)

Multiple unions with separate bargaining (MULTI2)

Union decided or negotiated workplace change (CHANGE)

Union resisted workplace change (RESIST)

Management strongly recommends unionization (REC)

Closed shop (pre or post) (CSHOP) in dealing with management (NONUREP)

$\mathrm{N}$ 
Table 7: Outcome Measures, Private Sector

\begin{tabular}{|c|c|c|c|}
\hline Workplace/Worker level & Definition & Mean & s.e. \\
\hline \multirow[t]{3}{*}{ Financial performance } & better than average $=3$ & 59.9 & \\
\hline & about average $=2$ & 33.0 & \\
\hline & worse than average $=1$ & 7.1 & \\
\hline \multirow[t]{3}{*}{ Labor productivity } & better than average $=3$ & 51.5 & \\
\hline & about average $=2$ & 42.1 & \\
\hline & worse than average $=1$ & 6.4 & \\
\hline \multirow[t]{4}{*}{ Labor productivity change } & better than average $=3$ & 46.3 & \\
\hline & about average $=2$ & 38.0 & \\
\hline & worse than average $=1$ & 10.7 & \\
\hline & a lot worse than average $=0$ & 5.0 & \\
\hline Change in employment & $\left(\mathrm{emp}_{1998}-\mathrm{emp}_{1993}\right) / \mathrm{emp}_{1993}$ & 0.62 & 6.93 \\
\hline $\begin{array}{l}\text { Climate (reported by } \\
\text { managers) }\end{array}$ & $\begin{array}{l}\text { binary variable, } 1=\text { good relations } \\
\text { between workers and managers }\end{array}$ & 0.12 & \\
\hline Quit rate & quits $_{1997-98} /$ employment ${ }_{1998}$ & 0.22 & 0.31 \\
\hline Absenteeism rate & $\%$ of work days lost $1997-98$ & 4.24 & 4.66 \\
\hline Log hourly wage & & 1.847 & 0.527 \\
\hline $\begin{array}{l}\text { Climate (reported by } \\
\text { workers) }\end{array}$ & $\begin{array}{l}\text { binary variable, } 1 \text { = good relations } \\
\text { between workers and managers }\end{array}$ & 0.22 & \\
\hline Sense of achievement & $\begin{array}{l}\text { binary variable, } 1=\text { (strongly) agree } \\
\text { that the worker gets a sense of } \\
\text { achievement }\end{array}$ & 0.59 & \\
\hline \multirow[t]{5}{*}{ Loyalty to the organization } & strongly agree $=5$ & 15.3 & \\
\hline & agree $=4$ & 49.2 & \\
\hline & neither agree nor disagree $=3$ & 24.0 & \\
\hline & disagree $=2$ & 7.8 & \\
\hline & strongly disagree $=1$ & 3.6 & \\
\hline \multirow[t]{5}{*}{ Shared values } & strongly agree $=5$ & 7.2 & \\
\hline & agree $=4$ & 41.6 & \\
\hline & neither agree nor disagree $=3$ & 35.6 & \\
\hline & disagree $=2$ & 11.9 & \\
\hline & strongly disagree $=1$ & 3.7 & \\
\hline \multirow[t]{5}{*}{ Pride in organization } & strongly agree $=5$ & 15.6 & \\
\hline & agree $=4$ & 39.3 & \\
\hline & neither agree nor disagree $=3$ & 32.7 & \\
\hline & disagree $=2$ & 8.1 & \\
\hline & strongly disagree $=1$ & 4.4 & \\
\hline
\end{tabular}

Note: Unweighted data from WERS98. 
Table 8: Strength of Union Effects on Outcomes - Workplace Level

\begin{tabular}{|c|c|c|c|c|c|c|c|}
\hline & Profitability & $\begin{array}{l}\text { Labor } \\
\text { productivity }\end{array}$ & $\begin{array}{c}\text { Labor } \\
\text { productivity } \\
\text { change }\end{array}$ & $\begin{array}{l}\text { Employment } \\
\text { growth }\end{array}$ & Quits & Absenteeism & Climate \\
\hline Effect of union recognized for pay bargaining & -ve, not sig. & -ve, not sig. & +ve, not sig. & -ve, $\mathrm{p}<0.05$ & -ve, $\mathrm{p}<0.05$ & + ve, $p<0.05$ & -ve, not sig. \\
\hline $\begin{array}{l}\text { Type of union where stronger version is } \\
\text { beneficial }(p<0.05) \text {, relative to weaker version }\end{array}$ & & & & RESIST & $\begin{array}{l}\text { REP, } \\
\text { MULTI1, } \\
\text { DENSE }\end{array}$ & & \\
\hline $\begin{array}{l}\text { Type of union where stronger version is } \\
\text { adverse }(p<0.05) \text {, relative to weaker version }\end{array}$ & RESIST & $\begin{array}{l}\text { RESIST, } \\
\text { DENSE, } \\
\text { RANGE, } \\
\text { MULTI2 }\end{array}$ & DENSE & REP & & $\begin{array}{l}\text { DENSE, } \\
\text { FAVES }\end{array}$ & RESIST \\
\hline $\mathrm{N}$ & 1236 & 1196 & 929 & 986 & 1299 & 1075 & 1393 \\
\hline
\end{tabular}

Notes: See Appendix Tables for full information on estimations.

Union types: REP: on-site union representative; MULTI1: multiple unions; FAVES: management favors unions; DENSE: $75 \%+$ union density at the workplace; RANGE: union negotiates across range of issues; MULTI2: multiple unions with separate bargaining; RESIST: union resisted workplace change 
Table 9: Strength of Union Effects on Outcomes - Worker Level

\begin{tabular}{|c|c|c|c|c|c|c|}
\hline & Climate & $\begin{array}{c}\text { Sense of } \\
\text { achievement }\end{array}$ & Loyalty & Shared values & $\begin{array}{c}\text { Pride in } \\
\text { organization }\end{array}$ & Log hourly wage \\
\hline Effect of union recognized for pay bargaining & -ve, $\mathrm{p}<0.01$ & -ve, $\mathrm{p}<0.01$ & -ve, $\mathrm{p}<0.01$ & -ve, $\mathrm{p}<0.01$ & -ve, $\mathrm{p}<0.01$ & + ve, $\mathrm{p}<0.01$ \\
\hline $\begin{array}{l}\text { Type of union where stronger version is } \\
\text { beneficial }(p<0.05) \text {, relative to weaker version }\end{array}$ & & & $\mathrm{REC} / \mathrm{CSHOP}$ & & REC/CSHOP & \\
\hline $\begin{array}{l}\text { Type of union where stronger version is } \\
\text { adverse }(p<0.05) \text {, relative to weaker version }\end{array}$ & $\begin{array}{l}\text { REP, } \\
\text { MULTI1, } \\
\text { DENSE, } \\
\text { RESIST, } \\
\text { RANGE, } \\
\text { CHANGE }\end{array}$ & $\begin{array}{l}\text { REP, } \\
\text { MULTI1, } \\
\text { DENSE, } \\
\text { RESIST }\end{array}$ & $\begin{array}{l}\text { DENSE, } \\
\text { MULTI1, } \\
\text { MULTI2 }\end{array}$ & $\begin{array}{l}\text { REP, } \\
\text { MULTI1, } \\
\text { RESIST }\end{array}$ & $\begin{array}{l}\text { DENSE, } \\
\text { MULTI1, } \\
\text { MULTI2 }\end{array}$ & $\begin{array}{l}\text { REP, } \\
\text { MULTI1, } \\
\text { DENSE, } \\
\text { RESIST, } \\
\text { RANGE } \\
\text { CHANGE, } \\
\text { REC/CSHOP }\end{array}$ \\
\hline $\mathrm{N}$ & 18051 & 18349 & 17943 & 17219 & 17968 & 17333 \\
\hline
\end{tabular}

Notes: See Appendix Tables for full information on estimations.

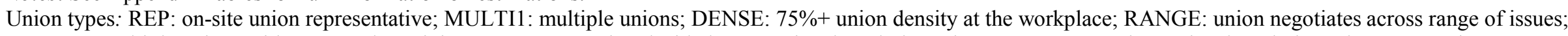

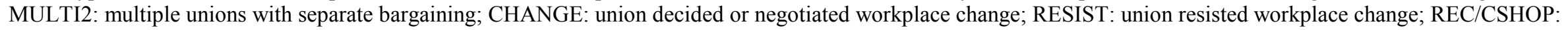
management strongly recommends unionisation or closed shop (pre- or post-). 
Appendix Table A.1: Impact of Unions on Financial Performance, Labor Productivity, Labor Productivity Change, and Employment Growth, WERS 98

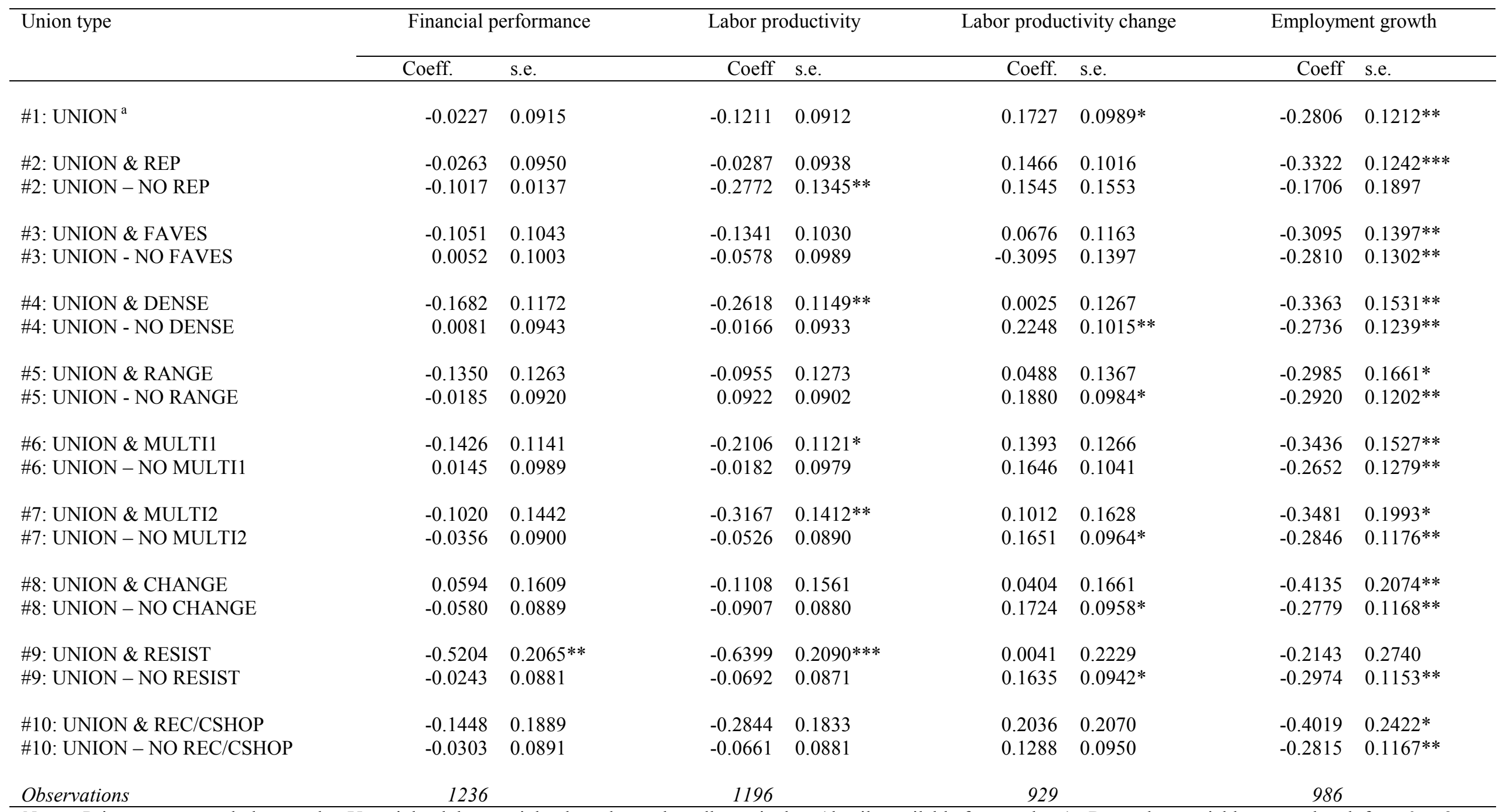

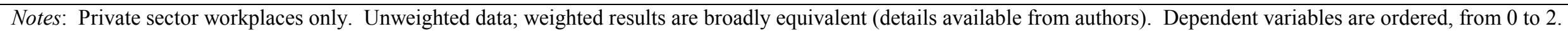

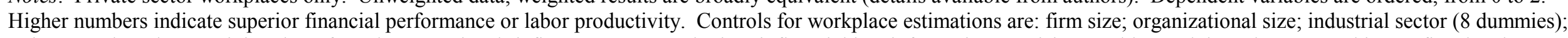

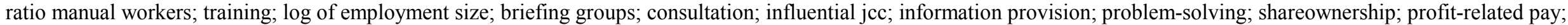
performance-related pay; establishment age.

${ }^{a}$ Also includes a control for nonunion representative. 
Appendix Table A.2: Impact of Unions on Quit Rate, Absenteeism Rate, and Climate, WERS 98

\begin{tabular}{|c|c|c|c|c|c|c|c|c|}
\hline \multirow[t]{2}{*}{ Union type } & \multicolumn{2}{|c|}{ Quit rate } & \multicolumn{2}{|c|}{ Absenteeism rate } & \multicolumn{2}{|c|}{$\begin{array}{c}\text { Climate } \\
\text { (manager reports) }\end{array}$} & \multicolumn{2}{|c|}{$\begin{array}{c}\text { Climate } \\
\text { (worker reports) }\end{array}$} \\
\hline & Coeff. & s.e. & Coeff. & s.e. & Coeff. & s.e. & Coeff & s.e. \\
\hline$\# 1: \mathrm{UNION}^{\mathrm{a}}$ & -0.0550 & $0.0123 * * *$ & 0.8805 & $0.1500 * * *$ & -0.0871 & 0.1178 & -0.1955 & $0.0176 * * *$ \\
\hline \#2: UNION \& REP & -0.0586 & $0.0125 * * *$ & 0.9174 & $0.1501 * * *$ & -0.0956 & 0.1190 & -0.2426 & $0.0190 * * *$ \\
\hline \#2: UNION - NO REP & -0.0185 & 0.0186 & 0.6387 & $0.2316^{* * *}$ & 0.0129 & 0.1888 & -0.0485 & $0.0291^{*}$ \\
\hline \#3: UNION \& FAVES & -0.0596 & $0.0138 * * *$ & 1.2099 & $0.1650 * * *$ & 0.0014 & 0.1343 & -0.2238 & $0.0206 * * *$ \\
\hline \#3: UNION - NO FAVES & -0.0397 & $0.0133 * * *$ & 0.5436 & $0.1597 * * *$ & -0.1327 & 0.1262 & -0.1670 & $0.0209 * * *$ \\
\hline \#4: UNION \& DENSE & -0.0808 & $0.0159 * * *$ & 1.2683 & $0.1840 * * *$ & -0.0851 & 0.1484 & -0.2478 & $0.0224 * * *$ \\
\hline \#4: UNION - NO DENSE & -0.0348 & $0.0125 * * *$ & 0.6654 & $0.1504 * * *$ & -0.0668 & 0.1199 & -0.1643 & $0.0196 * * *$ \\
\hline \#5: UNION \& RANGE & -0.0526 & $0.0168 * * *$ & 1.0659 & $0.1945 * * *$ & -0.1513 & 0.1560 & -0.2538 & $0.0252 * * *$ \\
\hline \#5: UNION - NO RANGE & -0.0478 & $0.0122 * * *$ & 0.7781 & $0.1491 * * *$ & -0.0463 & 0.1179 & -0.1751 & $0.0187 * * *$ \\
\hline \#6: UNION \& MULTI1 & -0.0788 & $0.0153 * * *$ & 0.9978 & $0.1850 * * *$ & -0.0610 & 0.1441 & -0.2593 & $0.0211 * * *$ \\
\hline \#6: UNION - NO MULTI1 & -0.0313 & $0.0130 * *$ & 0.7683 & $0.1589 * * *$ & -0.0796 & 0.1257 & -0.1411 & $0.0209 * * *$ \\
\hline \#7: UNION \& MULTI2 & -0.0760 & $0.0198 * * *$ & 0.9257 & $0.2360 * * *$ & -0.0377 & 0.1855 & -0.3445 & $0.0289 * * *$ \\
\hline \#7: UNION - NO MULTI2 & -0.0449 & $0.0119 * * *$ & 0.8447 & $0.1439 * * *$ & -0.0779 & 0.1142 & -0.1669 & $0.0182 * * *$ \\
\hline \#8: UNION \& CHANGE & -0.0682 & $0.0210 * * *$ & 1.1101 & $0.2432 * * *$ & 0.0392 & 0.1999 & -0.2651 & $0.0324 * * *$ \\
\hline \#8: UNION - NO CHANGE & -0.0466 & $0.0119 * * *$ & 0.8197 & $0.1434 * * *$ & -0.0867 & 0.1137 & -0.1850 & $0.0180 * * *$ \\
\hline \#9: UNION \& RESIST & -0.0782 & $0.0287 * * *$ & 1.1858 & $0.3303 * * *$ & -0.5467 & $0.2478 * *$ & -0.3564 & $0.0447 * * *$ \\
\hline \#9: UNION - NO RESIST & -0.0478 & $0.0117 * * *$ & 0.8412 & $0.1413 * * *$ & -0.0486 & 0.1130 & -0.1875 & $0.0177 * * *$ \\
\hline \#10: UNION \& REC/CSHOP & -0.0666 & $0.0257 * *$ & 1.1171 & $0.3148 * * *$ & 0.1051 & 0.2637 & -0.1764 & $0.0429 * * *$ \\
\hline \#10: UNION - NO REC/CSHOP & -0.0478 & $0.0119 * * *$ & 0.8304 & $0.1430 * * *$ & -0.0848 & 0.1136 & -0.1982 & $0.0179 * * *$ \\
\hline Observations & 1299 & & 1075 & & 1393 & & 18051 & \\
\hline
\end{tabular}

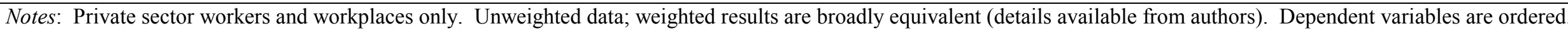

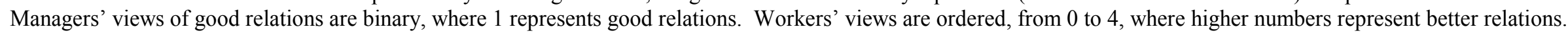

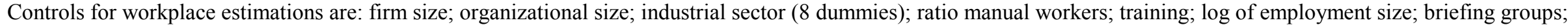

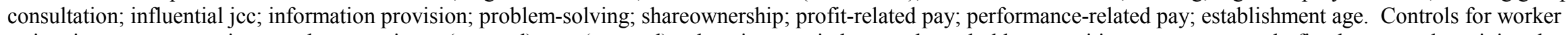

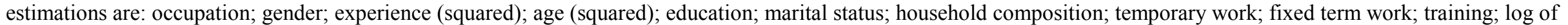
employment size; briefing groups; consultation; influential jcc; information provision; problem-solving; shareownership; profit-related pay; performance-related pay.

${ }^{a}$ Also includes a control for nonunion representative in workplace estimations only. 
Appendix Table A.3: Impact of Unions on Sense of Achievement, Loyalty, Shared Values, and Pride in Organization, WERS 98

\begin{tabular}{|c|c|c|c|c|c|c|c|c|}
\hline \multirow[t]{2}{*}{ Union type } & \multicolumn{2}{|c|}{ Sense of achievement } & \multicolumn{2}{|c|}{ Loyalty } & \multicolumn{2}{|c|}{ Shared values } & \multicolumn{2}{|c|}{ Pride in organization } \\
\hline & Coeff. & s.e. & Coeff & s.e. & Coeff. & s.e. & Coeff & s.e. \\
\hline \#1: UNION & -0.1293 & $0.0215^{* * *}$ & -0.1815 & $0.0180 * * *$ & -0.0709 & $0.0182 * * *$ & -0.1957 & $0.0177 * * *$ \\
\hline \#2: UNION \& REP & -0.1533 & $0.0233 * * *$ & -0.1924 & $0.0196 * * *$ & -0.0965 & $0.0197 * * *$ & -0.2012 & $0.0193 * * *$ \\
\hline \#2: UNION - NO REP & -0.0537 & 0.0354 & -0.1478 & $0.0293 * * *$ & 0.0092 & 0.0298 & -0.1783 & $0.0288 * * *$ \\
\hline \#3: UNION \& FAVES & -0.1495 & $0.0254 * * *$ & -0.1765 & $0.0213 * * *$ & -0.0551 & $0.0215 * *$ & -0.2048 & $0.0209 * * *$ \\
\hline \#3: UNION - NO FAVES & -0.1088 & $0.0254 * * *$ & -0.1866 & $0.0214 * * *$ & -0.0869 & $0.0216 * * *$ & -0.1865 & $0.0210 * * *$ \\
\hline \#4: UNION \& DENSE & -0.1875 & $0.0278 * * *$ & -0.2202 & $0.0235 * * *$ & -0.0891 & $0.0237 * * *$ & -0.2257 & $0.0230 * * *$ \\
\hline \#4: UNION - NO DENSE & -0.0944 & $0.0239 * * *$ & -0.1585 & $0.0200 * * *$ & -0.0599 & $0.0203 * * *$ & -0.1778 & $0.0198 * * *$ \\
\hline \#5: UNION \& RANGE & -0.1406 & $0.0309 * * *$ & -0.1561 & $0.0262 * * *$ & -0.0726 & $0.0265 * * *$ & -0.1795 & $0.0259 * * *$ \\
\hline \#5: UNION - NO RANGE & -0.1253 & $0.0228 * * *$ & -0.1904 & $0.0191 * * *$ & -0.0703 & $0.0194 * * *$ & -0.2013 & $0.0188 * * *$ \\
\hline \#6: UNION \& MULTI1 & -0.0996 & $0.0250 * * *$ & -0.2233 & $0.0224 * * *$ & -0.1154 & $0.0225 * * *$ & -0.2485 & $0.0220 * * *$ \\
\hline \#6: UNION - NO MULTI1 & 0.3199 & $0.1103 * * *$ & -0.1460 & $0.0209 * * *$ & -0.0324 & 0.0213 & -0.1506 & $0.0207 * * *$ \\
\hline \#7: UNION \& MULTI2 & -0.1955 & $0.0359 * * *$ & -0.2472 & $0.0311 * * *$ & -0.1121 & $0.0312 * * *$ & -0.2557 & $0.0303 * * *$ \\
\hline \#7: UNION - NO MULTI2 & -0.1165 & $0.0222 * * *$ & -0.1691 & $0.0185 * * *$ & -0.0629 & $0.0188 * * *$ & -0.1842 & $0.0182 * * *$ \\
\hline \#8: UNION \& CHANGE & -0.1864 & $0.0390 * * *$ & -0.1921 & $0.0342 * * *$ & -0.0812 & $0.0340 * *$ & -0.2019 & $0.0328 * * *$ \\
\hline \#8: UNION - NO CHANGE & -0.1206 & $0.0220 * * *$ & -0.1799 & $0.0184 * * *$ & -0.0693 & $0.0187 * * *$ & -0.1947 & $0.0182 * * *$ \\
\hline \#9: UNION \& RESIST & -0.2683 & $0.0543 * * *$ & -0.1111 & $0.0466 * *$ & -0.1596 & $0.0479 * * *$ & -0.2173 & $0.0453 * * *$ \\
\hline \#9: UNION - NO RESIST & -0.1223 & $0.0216^{* * *}$ & -0.1851 & $0.0181 * * *$ & -0.0665 & $0.0183 * * *$ & -0.1946 & $0.0178 * * *$ \\
\hline \#10: UNION \& REC/CSHOP & -0.0813 & 0.0499 & -0.0822 & $0.0441^{*}$ & -0.0002 & 0.0449 & -0.0716 & $0.0420 *$ \\
\hline \#10: UNION - NO REC/CSHOP & -0.1341 & $0.0218 * * *$ & -0.1886 & $0.0182 * * *$ & -0.0770 & $0.0185 * * *$ & -0.2048 & $0.0179 * * *$ \\
\hline Observations & 18349 & & 17943 & & 17219 & & 17968 & \\
\hline
\end{tabular}

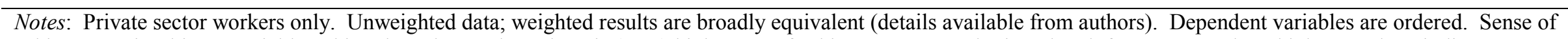

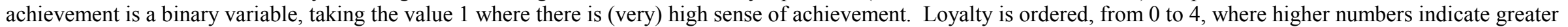

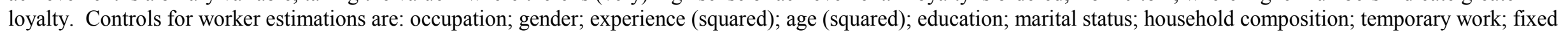
term work; training; log of employment size; briefing groups; consultation; influential jcc; information provision; problem-solving; shareownership; profit-related pay; performance-related pay. 
Appendix Table A.4: Impact of Unions on the Wage Premium, WERS 98

\begin{tabular}{|c|c|c|}
\hline \multirow[t]{2}{*}{ Union type } & \multicolumn{2}{|c|}{$\begin{array}{l}\text { Wage premium } \\
\text { log hourly wage }\end{array}$} \\
\hline & Coeff. & s.e. \\
\hline \#1: UNION & 0.0373 & $0.0061 * * *$ \\
\hline \#2: UNION \& REP & 0.0470 & $0.0065 * * *$ \\
\hline \#2: UNION - NO REP & 0.0069 & 0.0102 \\
\hline \#3: UNION \& FAVES & 0.0389 & $0.0070 * * *$ \\
\hline \#3: UNION - NO FAVES & 0.0356 & $0.0071 * * *$ \\
\hline \#4: UNION \& DENSE & 0.0748 & $0.0075 * * *$ \\
\hline \#4: UNION - NO DENSE & 0.0148 & $0.0068 * *$ \\
\hline \#5: UNION \& RANGE & 0.0636 & $0.0083^{* * *}$ \\
\hline \#5: UNION - NO RANGE & 0.0282 & $0.0064 * * *$ \\
\hline \#6: UNION \& MULTI1 & 0.0999 & $0.0070 * * *$ \\
\hline \#6: UNION - NO MULTI1 & -0.0162 & $0.0072 * *$ \\
\hline \#7: UNION \& MULTI2 & 0.0955 & $0.0093 * * *$ \\
\hline \#7: UNION - NO MULTI2 & 0.0261 & $0.0063 * * *$ \\
\hline \#8: UNION \& CHANGE & 0.0805 & $0.0099 * * *$ \\
\hline \#8: UNION - NO CHANGE & 0.0307 & $0.0063 * * *$ \\
\hline \#9: UNION \& RESIST & 0.0838 & $0.0146^{* * *}$ \\
\hline \#9: UNION - NO RESIST & 0.0350 & $0.0061 * * *$ \\
\hline \#10: UNION \& REC/CSHOP & 0.0663 & $0.0146^{* * *}$ \\
\hline \#10: UNION - NO REC/CSHOP & 0.0380 & $0.0062 * * *$ \\
\hline Observations & 17333 & \\
\hline \multicolumn{3}{|c|}{$\begin{array}{l}\text { Notes: Private sector workplaces only. Unweighted data; weighted results } \\
\text { are broadly equivalent (details available from authors). Dependent variable } \\
\text { is log hourly wage. Controls for worker estimations are: occupation; } \\
\text { gender; experience (squared); age (squared); education; marital status; } \\
\text { household composition; temporary work; fixed term work; training; log of } \\
\text { employment size; briefing groups; consultation; influential jcc; information } \\
\text { provision; problem-solving; shareownership; profit-related pay; } \\
\text { performance-related pay. }\end{array}$} \\
\hline
\end{tabular}




\section{IZA Discussion Papers}

No.

Author(s)

G. Fella

P. Manzini

M. Mariotti

440

G. Bertola

S. Hochguertel

W. Koeniger

441

C. W. Sibley

P. P. Walsh

M. Lindahl
R. Lalive

J. Zweimüller

K. L. Papps

J. O. Newell

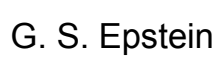

E. Yashiv

M. Fertig

C. M. Schmidt

M. P. Keane

E. S. Prasad

B. R. Chiswick

P. W. Miller

B. R. Chiswick

Y. L. Lee

P. W. Miller

B. R. Chiswick

P. W. Miller

B. R. Chiswick

Y. Liang Lee

P. W. Miller

P. Carneiro

K. T. Hansen

J. J. Heckman

W. Koeniger

J. T. Addison

C. R. Belfield
Title

Area

Date

Does Divorce Law Matter?

1

$02 / 02$

Dealer Pricing of Consumer Credit

7

$02 / 02$

Earnings Inequality and Transition: A Regional

Analysis of Poland

Estimating the Effect of Income on Health and Mortality Using Lottery Prizes as Exogenous

Source of Variation in Income

Identifying Functional Labour Market Areas in

New Zealand: A Reconnaissance Study Using

Travel-to-Work Data

Benefit Entitlement and the Labor Market:

6

$02 / 02$

Evidence from a Large-Scale Policy Change

$03 / 02$

Informational Cascades and Decision to Migrate

$03 / 02$

Frictions

Mobility within Europe - What do we (still not) 6 know?

$03 / 02$

Inequality, Transfers and Growth: New Evidence 4 from the Economic Transition in Poland

03/02

Do Enclaves Matter in Immigrant Adjustment? 1

$03 / 02$

Schooling, Literacy, Numeracy and Labor

$03 / 02$ Market Success

The Complementarity of Language and Other Human Capital: Immigrant Earnings in Canada

$03 / 02$

Longitudinal Analysis of Immigrant Occupational 1

03/02 Mobility: A Test of the Immigrant Assimilation Hypothesis

Removing the Veil of Ignorance in Assessing the 6 Distributional Impacts of Social Policies

Defensive Innovations

Unions and Establishment Performance:

3

03/02

Employee Relations Surveys

An updated list of IZA Discussion Papers is available on the center's homepage www.iza.org. 